\title{
They're Throwing Mud at Us. At Least Now They Have a Reason: Work, Control and Values in Teachers' Work
}

\author{
Pawel Krzyworzeka \\ Kozminski University, \\ 57/59 Jagiellońska St., 03-301 Warsaw, Poland \\ Amanda Krzyworzeka \\ University of Warsaw \\ Krakowskie Przedmieście 26/28, 00-927 Warszaw, Poland \\ cross $^{\text {ref }}$ http://dx.doi.org/10.5755/j01.ppaa.20.1.28463
}

\begin{abstract}
This research aims to understand how teachers perceive control mechanisms embedded in the educational system in Poland. In the article, we analyse teachers and school administrators' online discussions evoked by the decision of Polish Ministry of National Education to close schools in March 2020 in order to protect teachers and students from coronavirus infection. We show that management control mechanisms are crucial in understanding teachers and school administrators' behaviour. On the one hand, direct forms of control frustrate and demotivate teachers. On the other hand, a combination of diverse forms of control makes teachers comply and continue working despite the growing will to rebel against the system. We argue that the COVID pandemic exposed previously existing problems; therefore, the article's findings are also applicable beyond the pandemic context.
\end{abstract}

Keywords: management control, COVID-19, educational system, Poland, values, work, levers of control

Raktažodžiai: rizikos vadyba, COVID-19, švietimo sistema, Lenkija, vertybès, darbas, rizikos lygiai

\section{Introduction}

In this article, we focus on the response of teachers and school principals to regulations introduced by the Ministry of Education of the Republic of Poland in March 2020. New rules forced schools to a sudden transition from traditional teaching to remote education. We argue that this crisis has not created but only exposed pre-existing tensions and problems in the system. Our study aimed at understanding teachers' work-related issues that are relevant beyond the pandemic context ${ }^{1}$.

Polish social scientists are studying diverse aspects of the COVID-19 pandemic. Research findings address the economic effects of the pandemic (Korzeb \& Niedziółka, 2020; Roman et al., 2020) and psychological aspects of it (Debowska et al., 2020; Malesza \& Kaczmarek, 2021; Moroń \& Biolik-Moroń, 2021; Nowicki et al., 2020). Another set of literature deals with changes in lifestyles and everyday choices under the lockdown (Chodkiewicz et al., 2020; Sidor \& Rzymski, 2020; Sułkowski \& Ignatowski, 2020).

There are also studies with a focus on educational issues during the pandemic (Parczewska, 2020; Popyk, 2020; Torres et al., 2020). However, they deal with crisis-related problems that emerged during 2020, for example, the question of parents being obliged to homeschool their children (Parczewska, 2020) or solutions for conducting practical education online (Torres et al., 2020). In turn, our article offers an analysis of control mechanisms in education, a phenomenon that is neither new nor resulting from the pandemic itself. The unusual situation caused by the COVID-19 pandemic has brought previously existing tensions into sharp focus.

\footnotetext{
${ }^{1}$ The article is partly based on research funded by the Polish National Science Centre grant no. 2013/09/B/HS3/04302
} 
As schools were closed, teachers and students had to move their education activities online. The shift from offline to online education was very sudden; offline education was shut down almost overnight and schools had only a few days to adjust to the new circumstances. The Polish Ministry of Education announced on 11 March 2020 that educational activities of schools were temporarily limited $^{2}$. Starting from 12 March 2020 until 25 March 2020 all kindergartens, primary and secondary schools, and other educational institutions listed in the regulation had to suspend their teaching and educational activities. On 20 March, the Ministry issued a new Ordinance ${ }^{3}$ to regulate the rules of remote education after 25 March, i.e. after the two weeks of suspension of teaching classes.

The chart below illustrates how sudden the move to online education was for teachers. The graph shows the popularity of the search term "nauka zdalna" ("remote education" in Polish) in the Google search engine in the school year 2019/2020. As we can see, until the first days of March 2020, this term was not even recorded by Google Trends. The popularity of the term began to proliferate in the week of 8-14 March and in the following two weeks it skyrocketed to the highest level in history. Our study covers precisely this period.

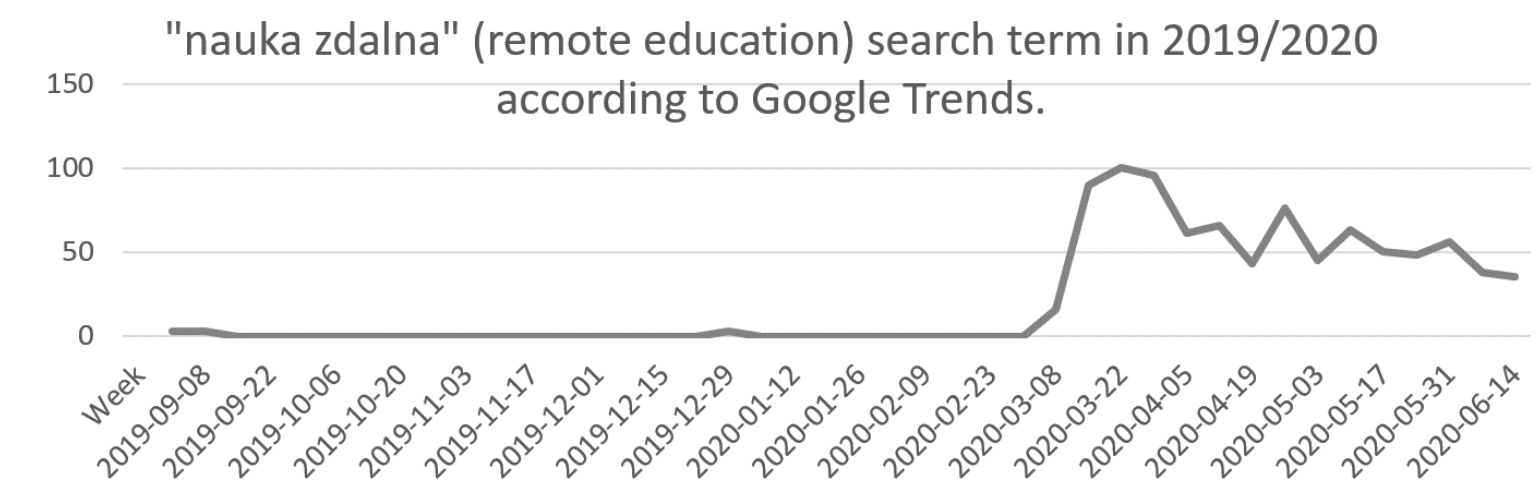

Fig.1. The popularity of the search term "nauka zdalna" ("remote education" in Polish) in the school year 2019/2020 according to the Google Trends

Source: https://trends.google.pl/.

The Ordinance of the Ministry of Education of 11 March 2020 sparked many controversies over school-level decisions that had to be made as a consequence of this regulation. The Ordinance states that "Temporary limitation of the functioning of units of the educational system (...), consists

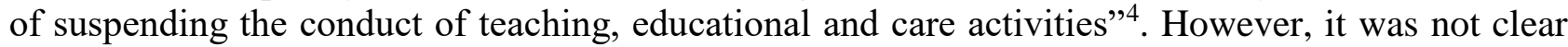
what work teachers should perform during the two weeks of suspension of teaching classes. Consequently, municipalities (which are the leading and funding authorities of schools) and school administrators had to decide whether teachers were entitled to full remuneration for their work.

Ambiguities about what teachers were supposed to do and what remuneration they were supposed to get for it provoked a nationwide discussion among teachers. In this paper we analyse this discourse. Teachers and administrators shared practical solutions about remote education on web forums and Facebook groups. Administrators also sought help there in interpreting the regulation and

\footnotetext{
${ }^{2}$ Polish Ministry of National Education Ordinance of 11 March 2020. Rozporządzenie Ministra Edukacji Narodowej z dnia 11 marca $2020 \mathrm{r}$. W sprawie czasowego ograniczenia funkcjonowania jednostek systemu oświaty w związku z zapobieganiem, przeciwdziałaniem i zwalczaniem COVID-19. Retrieved January 29, 2021, from https://isap.sejm.gov.pl/isap.nsf/DocDetails.xsp?id=WDU20200000410

${ }^{3}$ Polish Ministry of National Education Ordinance of 20 March 2020. Rozporządzenie Ministra Edukacji Narodowej z dnia 20 marca 2020 r. W sprawie szczególnych rozwiązań w okresie czasowego ograniczenia funkcjonowania jednostek systemu oświaty w związku z zapobieganiem, przeciwdziałaniem i zwalczaniem COVID-19. Retrieved February 5, 2021, from http://isap.sejm.gov.pl/isap.nsf/DocDetails.xsp?id=WDU20200000493

${ }^{4}$ Polish Ministry of National Education Ordinance of 11 March 2020: 2 para. 1.
} 
labour law. Besides, teachers actively engaged in criticising curators of education, ministries, school directors and fellow teachers. Everyone involved shared their fears and frustrations.

We analysed posts and comments published between 10-27 March 2020 on two Facebook groups for teachers and school heads. We aimed to identify the growing teachers' dissatisfaction with work in Poland. The debate about education under the lockdown that took place in Facebook groups gave us a unique opportunity to observe power dynamics in the educational system from the teachers' perspective. As a result, we discovered that management control mechanisms are crucial to understanding teachers' and school administrators' behaviour. On the one hand, direct forms of control frustrate and demotivate teachers. On the other hand, a combination of diverse forms of control makes teachers comply and continue working despite the growing will to rebel against the system.

In the next section of the article, we discuss theories of management control. We refer to the broad understanding of control in which control takes explicit and implicit forms and should be analysed as an interdependent system of diverse mechanisms. In the methods section, we describe how we gathered and analysed empirical material. The results section is organised around themes emerging from the analysis of the material. The primary purpose of the section was to allow readers to empathise with the teachers' community and see the problems they faced from their internal perspective. Finally, in the discussion section, we argue that teachers' work is shaped mainly by explicit forms of bureaucratic control that teachers find oppressive.

\section{Management control}

The process of influencing people's behaviour is the core element of the different ways in which control is understood (Flamholtz et al., 1985). Diverse types of control have been developed in an organisational and institutional setting to gain control over the behaviour of people. Typical types of control include reward systems, personal supervision, standard operating procedures, performance measurement, etc. According to Herman, who analysed control in the context of corporate law, control is "a term used in many disciplines as well as in common parlance. It relates to power - the capacity to initiate, constrain, circumscribe, or terminate action, either directly or by influence exercised on those with immediate decision-making authority" (Herman, 1982, p. 17). Herman's observation that the term control functions in both academic and everyday discourse is essential for our article. Control appears in our empirical material repeatedly; however, when teachers refer to control, they mean control only in its narrow sense.

In management, diverse types of control are usually presented as a package (Malmi \& Brown, 2008). Although researchers categorise types of control differently, there is a general agreement that relations between identified categories of control are complementary, not substitutional. For Ouchi, control could take the form of market, bureaucracy or clan where the latter is an implicit control while the former is explicit (Ouchi, 1980). Other commonly used typology of control consists of formal and informal types of control (Johnson \& Gill, 1993). However, the one that captures all mentioned above categories is a distinction between technocratic and socio-ideological forms of control (Alvesson \& Kärreman, 2004). Technocratic control is explicit, formal, bureaucratic and often measure-based. Socio-ideological control, on the other hand, is implicit, informal, based on values and culture. Alvesson and Kärreman (2004) state that both forms of control exist in every organisation. The relation between technocratic and socio-ideological is complementary. The composition of these two forms of control depends on the type of organisation, its lifecycle and the general context.

The book titled Levers of Control by Robert Simons (Simons, 2013) is one of the most influential works that discusses balancing diverse types of control. Simons' primary focus is on how diverse control systems limit and encourage creativity. The dialectical opposition between control and creativity was identified by other researchers as a core challenge in the functioning of bureaucracy (Adler \& Borys, 1996), in individual motivation and collaborative projects (Adler \& Chen, 2011) and in designing management control systems (Mundy, 2010). According to Simons, managers have to apply not one, but a set of mutually interdepended tools to balance empowerment and accountability 
effectively. In his framework, Simons refers to these tools as levers of control and usefully groups them into four categories: 1) belief systems, 2) interactive control systems, 3) diagnostic control systems and 4) boundary systems.

Belief systems and interactive control systems are positive forces as they motivate, inspire and reward. Beliefs facilitate commitment to organisational values, encourage employees to search for innovative solutions and new opportunities. Presentations of awards are among the few explicitly mentioned examples of actions that senior managers take to signal the importance of beliefs systems and promote specific values. Other examples are speeches and group meetings. In this article we argue that values internalised by teachers play a unique role as a control mechanism in our focal case.

Interactive control systems, similarly to beliefs systems, positively stimulate organisational learning. They are a formal mechanism used by senior managers regularly "to involve themselves ... in the decision activities of subordinates" (Simons, 2013, p. 95). It takes the form of two-way communication in which management gathers information from different parts of the organisation to develop strategic plans based on local knowledge and emergent strategies.

Managers need mechanisms that would allow them to inspire and promote innovations and control the ways organisational goals are achieved. Beliefs and interactive control systems enable control. However, to maintain efficiency organisations take advantage of two coercive systems: diagnostic control systems and boundary systems.

Diagnostic control systems in Simons' framework are the "formal information systems that managers use to monitor organisational outcomes and correct deviations from present standards of performance" (Simons, 2013, p. 59). The constituting characteristics of these systems include the ability to measure specific output: this allows to compare results against predetermined standards and correct deviations from the norm. In the context of the educational system, the diagnostic control system would measure the level of coverage of predefined learning outcomes. The diagnostic control system is "the backbone of traditional management control" (Simons, 2013, p. 59). The diagnostic control systems are designed to increase the predictability of goal achievement and free managers' attention.

The last type of control system identified by Simons is the boundary system, which includes tools such as codes of conduct and other formal rules which do not offer positive ideas but constrain people's behaviour. Boundary systems limit and narrow down creativity inspired by belief systems and interactive control systems.

Simons clearly distinguishes four levels of control for analytical purposes. Moreover, he presents the relation between them as complementary and harmonious. Two of them, belief systems and interactive control systems, are enablers; they motivate and inspire. The remaining two levers, diagnostic control systems and boundary systems, narrow down the limitless creativity inspired by the two first levers. Each lever pair consists of a technocratic lever (interactive control systems and interactive control systems) and a socio-ideological lever (belief systems and boundary systems). And again, the relation between them is complementary. These levers support each other mutually. When measure-based technocratic forms of control fail (gaps in the system), the socio-ideological levers prevent employees from opportunistic behaviour. People are supposed to do the right things for the right reasons.

Our argument is instrumental in highlighting that control in everyday use usually refers to a limited number of possible forms of control in each organisation. Simons offers a useful framework that covers diverse controls and stresses the importance of relations between them.

\section{Methodology}

Initially, the study aimed to understand teachers' perception of control and the role of values in their work. However, the management control theory that we finally applied in this paper considers values as a specific control mechanism. Therefore, our research questions focus on the role of control mechanisms in general.

1. How do teachers perceive control exercised over them? 
2. How do diverse forms of control influence teachers' decisions regarding the organisation of their work?

Our research approach situates this study within the interpretative paradigm. We are interested in the forms of control embedded in the system. However, to better understand the system-level control mechanisms, we focus on the perspective of organizational actors. Consequently, to learn more about the insiders' view, we conducted an interpretative content analysis of two relatively big Facebook groups created for teachers and schools' administrators. The first group consists of 20 thousand users and the second of almost 30 thousand users. Several posts are published each day in these groups and virtually each post inspires a discussion, sometimes comprising hundreds of comments. The empirical material we used in our analysis consisted of the posts and comments published by groups members.

We limited our scope to the posts published between 10-27 March 2020, one day before the Ministry published the Ordinance of 11 March to inform about the temporary suspension of educational activities for two weeks, and two days after schools started remote education regulated by the Ordinance of 20 March. We saved 66 posts and associated comments as pdf documents. The number of comments ranges from 35 to 500 per post. We gathered almost 700 pages of educationfocused written online debate among Facebook group users. We analysed empirical material by performing open coding, followed by selective coding around emerging categories.

To protect the identity of the authors, we anonymised all the quoted statements. Furthermore, to prevent the identification of specific persons, we do not provide names of the Facebook groups and present the English translation of the quotes that were originally written in Polish.

\section{Results}

The teaching load and work-hours are essential topics in teachers' online discussions. Before we proceed with the presentation of empirical material, it is necessary to mention that a full-time contract of a school teacher consists of 40 hours of work per week, including 18 contact hours, i.e. lessons in the classroom 5 . For the remaining 22 hours, teachers are obliged to pursue "activities arising from the school's statutory tasks" and "activities related to preparation, self-training and

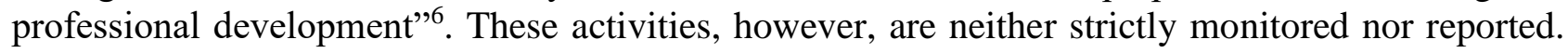
That is why the schedule of lessons is the critical element that organises teachers' work.

This eighteen-hour work week is an image that was brought to the public awareness. In many earlier debates on the educational system, commentators repetitively raised the argument that teachers are not burdened with work. Critics highlight that teachers work only 18 hours a week and have more than two months of paid leave. Usually, a teacher's job is compared to other full-time positions (40 hours of monitored work time and 20-26 days of paid leave).

According to the Ordinance of 11 March 2020, "The temporary limitation of the functioning of the educational system institutions (...) consists of suspending the conduct of teaching, educational and care activities" ( $\$ 3$, para. 1). Schools cancelled classes and closed their buildings. Both teachers and pupils stayed at home. Formally, teachers were supposed to continue working and get their full remuneration. However, many controversies arose around tasks teachers should perform and forms of accounting for them: the suspension of lessons for two weeks in March 2020 deprived schools of the fundamental accountability tool.

The empirical material shows that only conducting lessons in class and realising the official teaching programme are recognised as valid work. However, control of the latter boils down to reporting topics covered via IT systems. During the two weeks of the suspension, this was not allowed. Our analysis shows that teachers were concerned with what they should do and how they

\footnotetext{
${ }^{5}$ http://isap.sejm.gov.pl/isap.nsf/DocDetails.xsp?id=WDU20190002215

${ }^{6}$ Chapter four, Article 42, second paragraph. http://isap.sejm.gov.pl/isap.nsf/DocDetails.xsp?id=WDU20190002215
} 
should show that they are working. Not only their remuneration, but also their public image was at stake.

The following comment from 11 March 2020 is a good illustration of our observation that teachers are concerned that society evaluates them using categories typical for a traditional full-time, nine-to-five job.

Once again, society will throw mud at us.

(Teacher A)

Again, they'll say we have so much free time...

(Teacher C)

Right. They'll be resentful that because of the virus they have $80 \%$, and we have $100 \%$

(Teacher E)

LOL. Let them come work at school. There are shortages of staff...

(Teacher F)

What does society have to do with it? It's the government's decision. This is an emergency. Besides, this fear of society is a phobia. A teachers' curse. Get over it once and for all!!!

(Teacher $G$ )

And even without that, they're throwing mud at us. At least now they have a reason.

(Teacher J)

And let them throw mud at us, we should treat it as the norm by now. But... Who is going to teach people how to read, write and count...

(Teacher $K)$

As we can see in the excerpt above, teachers' show mixed reactions to the problem. All the debaters feel that they are being mistreated because society does not understand the nature of their work. However, the comment "At least now they have a reason" suggests that measuring the value of work with the number of hours spent in the classroom is partly internalised by teachers. If contact hours are not counted, there is nothing left that teachers can use to show, even to themselves, as proof of good work.

Formally, educational activities were suspended. According to the Ministry's interpretation of the regulation, the only activity allowed during that period was supporting pupils in self-education. However, some schools and individual teachers decided to introduce new teaching material, set obligatory assignments and give marks. In one comment from $11 \mathrm{March}$, we read: „I'm doing $e$ learning, so I'm still doing my job. It may even take more time than giving a regular lesson. Gee, how envious people are, even in times of a possible pandemic...". These obligatory assignments often irritated parents who had to explain new material to their children, although they had neither time nor competence. For teachers, developing and sending materials has become tangible proof that they were working. If necessary, they would be able to provide the evidence. As one teacher expressed it: „One day, this whole thing will calm down and we will have to account for what we've been doing during this time. I know the reality and I understand your fears, I have them too (17.04)“".

Indeed, regional curators of education, who act as a controlling authority, sent surveys to schools asking about the activities carried out during these two weeks. Although teachers were not surprised to receive the questionnaire, it stirred them up. The quote below comes from a post published in response to such a survey.

We have hardly received any support (the computers promised for students haven't arrived yet), but they offered a lot of "good" advice. And now they're back to what they know best: CONTROL. They 
flooded schools with various surveys, such as this one [link $\left.{ }^{7}\right]$. Maybe some employee of these institutions (and I think they're following this group) will tell us what the purpose is (in addition to having to create another ton of documentation). (17.03).

The user's reaction to this post is symptomatic. Some teachers accepted this reporting as a necessary, albeit useless, element of the system, a necessary evil. Others felt that teachers should resist and rebel.

I filled it out, too. This is our reality. There's always been bureaucracy at school. Everyone controls everyone. Let's do our job and take care of our health.

(Teacher A)

Maybe that's because everyone agrees and sends back these reports and tables without any objection. (17.03)

(Teacher B)

As many examples from our empirical material show, teachers and school principals find bureaucratic control over them excessive, useless and even harmful. Reporting generates unproductive but time-consuming tasks and limits autonomy and creativity. However, schools prefer to stick to formal requirements because of the fear of negative consequences. This situation creates tension between teachers' individual needs to express their agency and the need to comply, as expected by the authorities.

The comment below illustrates the tension between actions resulting from the realisation of formal requirements and activities motivated by emotions and values. The author stresses the legal aspect of what was required of teachers.

Assignments? What are you talking about? Didactic classes are suspended. There are no exceptions. You can't introduce new material, you can't do tests, you can't do credit work, you can't mark assignments. You can't leave any trace in the class register ${ }^{8}$.

The very last sentence signals the importance of formal reporting. Because of the suspension of classes, teachers were not allowed to perform regular educational activities. The important practical consequence of this formal restriction was to keep the documentation clear. Another teacher responded:

I agree on that - we have 'days off' in the class register, and we don't record attendance or anythingeverything is according to the principle 'we offer possibilities and what kids do with them is their own responsibility'.

The following response also highlights that the only thing teachers can do is encourage and support pupils: „Encourage - that's the keyword! Just pass the material, no classes, no grades, no attendance checking ".

Another teacher joined the discussion by observing that some colleagues act differently: „There are overzealous teachers. The worst thing to do is to introduce new material by sending the guidelines like 'please read the material and do exercises on pages 50-65' (14.03)". As the quote shows, overloading pupils with teaching material creates proof of teachers' high performance at work. Colleagues call such teacher "overzealous". This exact term is used frequently in posts and comments.

It's the directors and the overzealous teachers who are self-centred and put themselves on a pedestal. Parents are fed up, for, after a day at work, they still have to help their children do their homework. And if they are unfortunate to have an overzealous teacher... This is a disaster!

\footnotetext{
${ }^{7}$ Archived snapshot the survey: https://web.archive.org/web/20210204141539/https://www.kuratorium.waw.pl/ s4/form/dodaj629,Monitorowanie-realizacji-zajec-z-zakresu-pomocy-psychologiczno-pedagogicznej.html

${ }^{8}$ A complex IT system that most schools in Poland use to manage class schedules, register topics covered by teachers, pupils' marks, attendance and communicate with parents.
} 
The overzealousness of directors and the teachers is shocking.

I don't understand this competition of giving students more and more work.

Because we're overzealous. But we still get our a** kicked all the time.

According to the teachers cited above, their overzealous colleagues were keeping themselves busy at the children's expense. All the tasks and materials sent to the students served to provide evidence that the school was working.

Emotions and values play an essential role in teachers' decisions. In the material, we identified four subsets of values that are in dynamic interplay with each other. Stability and safety create the first and fundamental subset of values we identified. The fear of the level of wages being reduced was the first topic discussed by the online community we studied. Another subgroup consists of values like idealism, mission-oriented work, calling or even a sacrifice. These values represent teachers who criticise their colleagues who do whatever it takes not to lose a penny of their paycheck. Another subset of values includes the need for respect and dignity at work. Teachers repeatedly conclude that the lack of respect for their work results from teachers treating their work as a realisation of a mission that requires sacrifices, not calculations.

The table below presents a selection of quotes that illustrate three subsets of values essential for teachers as a professional group.

\section{Table 1. Subsets and quotes}

\begin{tabular}{|c|c|}
\hline $\begin{array}{c}\text { SUBSETS OF } \\
\text { TEACHERS VALUES }\end{array}$ & QUOTES FROM ONLINE DISCUSSIONS \\
\hline Safety and stability & $\begin{array}{l}\text { If classes are suspended, will teachers get salaries? (10.03) } \\
\text { I have to go to school for over } 150 \% \text { more hours instead of the } 2 \text { lessons I have in the } \\
\text { original schedule, I have to be at work for } 5 \text { hours and } 15 \text { minutes. (12.03) } \\
\text { So someone might ask, "Well, if we can't work, will they pay us our wages?" Of } \\
\text { course. This is regulated by the Labour Code (Article } 81 \text { ) - wages are payable for the } \\
\text { very readiness to work, even if the employer is not able to commission the worker. } \\
\text { (16.03) } \\
\text { We're entitled to a salary and there should be no discussion here. However, the } \\
\text { requirements for teachers are unacceptable. Conducting classes on private computers... } \\
\text { that's something we should object to. (16.03) } \\
\text { I'm asking for regulations that dictate the use of personal equipment for work. Will the } \\
\text { school pay my internet and electricity bills? We know we'll get only the base salary. } \\
\text { (17.03) } \\
\text { Can we (as directors) currently evaluate teachers' performance based on their remote } \\
\text { work? (20.03) } \\
\text { To avoid the consequences, teachers will start "putting lipstick on a pig", which is } \\
\text { reporting lessons topic from the curriculum base, which were supposedly realised } \\
\text { remotely. (25.03) }\end{array}$ \\
\hline Idealism and mission & $\begin{array}{l}\text { In general, there is one conclusion - let's not disturb teachers, they can do it! (16.03) } \\
\text { My subject was not included in these materials. But what the hell! I can handle it } \\
\text { anyway. I'm not complaining. (16.03) } \\
\text { Many teachers go ahead and organise online teaching on their own, without any orders } \\
\text { "from above". The mission... (16.03) } \\
\text { Teacher A: Like most Polish langue teachers, I'm full of ideals, uncompromising and I } \\
\text { have an aversion to mediocrity. } \\
\text { Teacher B: My lovely Strongwoman". (23.03) }\end{array}$ \\
\hline
\end{tabular}

\footnotetext{
9 "Strongwoman" ("siłaczka" in Polish) is an important term used repeatedly to describe teachers who are idealists. The "Strongwoman" was a teacher, the title character of a famous short novel by Stefan Żeromski titled Siłaczka published in 1895. The novel tells the story of a young female teacher who, motivated by idealism, moved to the countryside to teach poor peasants. In Polish culture, the term Strongwoman symbolizes perseverance and idealism, but at the same time rather ineffective activities.
} 


\begin{tabular}{|l|l|}
\hline \multicolumn{1}{|c|}{$\begin{array}{c}\text { SUBSETS OF } \\
\text { TEACHERS VALUES }\end{array}$} & \multicolumn{1}{|c|}{ QUOTES FROM ONLINE DISCUSSIONS } \\
\hline \multirow{1}{*}{ Dignity and respect } & $\begin{array}{l}\text { The 'Strongwoman" taking part in the race to earn some pennies. They're going to } \\
\text { screw us as usual. (19.03) } \\
\text { The vast majority of us spent the weekend on training: How to teach remotely, ICT } \\
\text { tools, etc. We prepared a batch of materials that we kindly sent to the students on } \\
\text { Monday and some even on Sunday. We've shown that, as always, we're locked and } \\
\text { loaded. (17.03) }\end{array}$ \\
$\begin{array}{l}\text { I'm not the Strongwoman. I'm a realist. You have to live on something. (14.03) } \\
\text { I stopped filling out those surveys. No support, only control. That's not how it's } \\
\text { supposed to be. (15.03) } \\
\text { We're all in a difficult situation, bombarded by information, regulations, reminders... } \\
\text { Unfortunately, in many cases teachers are subjected to illegal requirements. That's a } \\
\text { lot of abuse. (16.03) } \\
\text { Observing the Ministry and curators' actions and the great heart of teachers, we are sad } \\
\text { to see the Ministry mindlessly attempting to bureaucratise remote teaching initiated by } \\
\text { teachers. Instead of giving the teachers confidence and gratitude, the Ministry treats } \\
\text { them condescendingly. No kindness, no appreciation. (17.03) }\end{array}$ \\
\hline
\end{tabular}

Source: Authors.

As we can see in this collection of quotes, the need for economic safety and respect and idealism are intertwined. In some cases, fostering one value is perceived as colliding with others. Idealism can lead to the exploitation of teachers by other stakeholders, which, as a consequence, erodes the prestige of this profession. However, the struggle for dignity and respect can, in turn, be perceived as caring for material gains only.

\section{Discussion}

Four levers of control may serve as a good guideline of the desired organisational design for management practitioners. However, as our focal case shows, the reality is much more complex than Simons' theoretical framework. What is missing in the model is recognition of possible frictions within and among levers. We can identify all four levers of control in the Polish educational system, but their relations are far from being harmonious. Our case tells a story of contradictions and blurred boundaries between diverse forces that influence teachers behaviour.

The Ministry of National Education Ordinance of 11 March 2020 was a two-page long document that was supposed to act as a boundary system; it introduced limits to organisational activities to minimise essential risks. The document ordered the temporary suspension of face-to-face lessons to protect teachers and students from the coronavirus infection. However, schools perceived the introduction of the Ordinance as interfering with pre-existing documents, such as school statuses, intra-school evaluation systems or even the Teacher's Charter, i.e., main bill regulating rights and duties of teachers in Poland. Teachers and pupils stayed at home, but limits imposed by the contradictory boundary systems made teachers and school administrators feel insecure about what they were allowed to do.

As our case shows, actions that schools and individual teachers undertook after 11 March varied enormously. Most of the teachers tried to establish at least a one-way type of communication with pupils. Some teachers sent out only optional teaching materials, but a group of educators pursued intensive teaching and evaluation of students' progress. Referencing the remaining three levers of control can usefully explain this diversity of responses to the Ordinance.

The popular use of the term "control" refers to what Simons calls diagnostic control systems, i.e., tools measuring progress against the plan to assure the predictable achievement of predefined goals. In the school context, two main forms of controls of this type are class schedules (the number of contact hours) and class registers (records of topics from the curriculum covered during each lesson).

Our case shows that the Polish educational system, as analysed from teachers' perspective, is overdependent on diagnostic control systems. When the Ordinance deprived schools of these tools, it 
appeared that there are no widely accepted forms of working with pupils other than giving grades and covering consecutive topics from the list.

At first, it seemed to be hard to identify the forth lever of control, i.e., the interactive control systems, in our case. This lever serves "top-level managers to focus on strategic uncertainties, to learn about threats and opportunities as competitive conditions change, and to respond proactively" (Simons, 1995, p. 10). However, the top-level authorities did not participate in the online discussion we analysed; therefore, we did not gain insight in their actions and motivations. However, the surveys that teachers received from controlling and funding institutions might be designed to serve as an interactive control tool. Importantly, teachers interpreted these surveys as a threat or an attempt to measure their performance; that is a form of the diagnostic control system and not the interactive control system.

Finally, we analysed the most complex and overlooked form of control, i.e., belief systems. They are composed of values, norms and social expectations that govern teachers and schools' behaviour. At least three sets of values are in constant interplay here. Teachers seek economic safety, to some extent they are also motivated by idealism, but they also seek recognition and respect. Lack of respect to their profession is a widely-shared sentiment in this community that provokes many members to oppose the system. However, idealism is one of the obstacles in the fight for dignity, higher wages and respect. Specifically, idealism is embedded in teachers' profession. For some, idealism is a significant internalised value. However, idealism is an important issue even for those who are mission-driven only to a limited extent. Society and higher-level institutions expect teachers to be idealists; this is a prominent trait of a good teacher.

\section{Conclusions}

We believe that harmonising various levers of control in Poland's educational system would improve teachers' work satisfaction and allow teachers to realise their full potential. Such a systemic change would require not only policy-level changes, but also implementation of new regulations. It would also require a nationwide debate about the role of a teacher. Schools would need to find new ways of measuring teachers' effort and communicating the value of their work. Idealism and being mission-driven do not serve well as defining characteristics of a teacher anymore. As one teacher said, the mission is a teachers' curse. One possible alternative would be to supplement or even replace idealism with professionalism in public discourse. Our empirical material signals that some teachers already started building their occupational identity as specialists and professionals. However, such a transition would require a cultural change. The fact that the term "Strongwoman", which was introduced to Polish literature almost 150 years ago, is still used today to describe mission-driven teachers perfectly illustrates how difficult this transition could be.

\section{References}

1. Adler, P. S., \& Borys, B. (1996). Two types of bureaucracy: Enabling and coercive. Administrative Science Quarterly, 41(1), 61-89.

2. Adler, P. S., \& Chen, C. X. (2011). Combining Creativity and Control: Understanding Individual Motivation in LargeScale Collaborative Creativity. Accounting, Organizations and Society, 36(2), 63-85.

3. Alvesson, M., \& Kärreman, D. (2004). Interfaces of control. Technocratic and socio-ideological control in a global management consultancy firm. Accounting, Organizations and Society, 29(3), 423-444.

4. Chodkiewicz, J., Talarowska, M., Miniszewska, J., Nawrocka, N., \& Bilinski, P. (2020). Alcohol consumption reported during the COVID-19 pandemic: The initial stage. International Journal of Environmental Research and Public Health, 17(13), 4677.

5. Debowska, A., Horeczy, B., Boduszek, D., \& Dolinski, D. (2020). A repeated cross-sectional survey assessing university students' stress, depression, anxiety, and suicidality in the early stages of the COVID-19 pandemic in Poland. Psychological Medicine, 1-4.

6. Flamholtz, E. G., Das, T. K., \& Tsui, A. S. (1985). Toward an integrative framework of organizational control. Accounting, Organizations and Society, 10(1), 35-50.

7. Herman, E. (1982). Corporate control,corporate power: A twentieth century fund study. Cambridge University. 
8. Johnson, P., \& Gill, J. (1993). Management Control and Organizational Behaviour. Sage.

9. Korzeb, Z., \& Niedziółka, A. (2020). Resistance of commercial banks to the crisis caused by the COVID-19 pandemic: The case of Poland. Equilibrium. Quarterly Journal of Economics and Economic Policy, 15(2), $205-234$.

10. Malesza, M., \& Kaczmarek, M. C. (2021). Predictors of anxiety during the COVID-19 pandemic in Poland. Personality and Individual Differences, 170, 110419.

11. Malmi, T., \& Brown, D. A. (2008). Management control systems as a package-Opportunities, challenges and research directions. Management Accounting Research, 19(4), 287-300.

12. Moroń, M., \& Biolik-Moroń, M. (2021). Trait emotional intelligence and emotional experiences during the COVID19 pandemic outbreak in Poland: A daily diary study. Personality and Individual Differences, 168, 110348.

13. Mundy, J. (2010). Creating dynamic tensions through a balanced use of management control systems. Accounting, Organizations and Society, 35(5), 499-523.

14. Nowicki, G. J., Ślusarska, B., Tucholska, K., Naylor, K., Chrzan-Rodak, A., \& Niedorys, B. (2020). The severity of traumatic stress associated with COVID-19 pandemic, perception of support, sense of security, and sense of meaning in life among nurses: Research protocol and preliminary results from Poland. International Journal of Environmental Research and Public Health, 17(18), 6491.

15. Ouchi, W. G. (1980). Markets, bureaucracies, and clans. Administrative Science Quarterly, 25(1), $129-141$.

16. Parczewska, T. (2020). Difficult situations and ways of coping with them in the experiences of parents homeschooling their children during the COVID-19 pandemic in Poland. Education 3-13, 1-12.

17. Popyk, A. (2020). The impact of distance learning on the social practices of schoolchildren during the COVID-19 pandemic: Reconstructing values of migrant children in Poland. European Societies, 1-15.

18. Roman, M., Niedziółka, A., \& Krasnodębski, A. (2020). Respondents' Involvement in Tourist Activities at the Time of the COVID-19 Pandemic. Sustainability, 12(22), 9610.

19. Sidor, A., \& Rzymski, P. (2020). Dietary choices and habits during COVID-19 lockdown: Experience from Poland. Nutrients, 12(6), 1657.

20. Simons, R. (1995). Control in an Age of Empowerment. Harvard Business Review, March-April, 5-12.

21. Simons, R. (2013). Levers of control: How managers use innovative control systems to drive strategic renewal. Harvard Business Press.

22. Sułkowski, Ł., \& Ignatowski, G. (2020). Impact of COVID-19 pandemic on organization of religious behaviour in different Christian denominations in Poland. Religions, 11(5), 254.

23. Torres, A., Domańska-Glonek, E., Dzikowski, W., Korulczyk, J., \& Torres, K. (2020). Transition to online is possible: Solution for simulation-based teaching during the COVID-19 pandemic. Medical Education, 54(9), 858-859.

Pawel Krzyworzeka, Amanda Krzyworzeka

\title{
Jie mus maudo purve. Šiuo metu jei bent jau turi priežastį: darbas, kontrolẻ ir vertybės mokytojų darbe
}

\author{
Anotacija
}

Šiuo tyrimu siekiama suprasti, kaip mokytojai suvokia Lenkijos švietimo sistemoje įdiegtus kontrolès mechanizmus dèl COVID-19. Straipsnyje analizuojame mokytojų ir mokyklų administratorių internetines diskusijas, kurias sukèlé Lenkijos švietimo ministerijos sprendimas uždaryti mokyklas $2020 \mathrm{~m}$. kovo mènesį, siekiant apsaugoti mokytojus ir mokinius nuo koronaviruso infekcijos. Straipsnyje atskleidžiama kaip valdymo kontrolès mechanizmų svarba norint suprasti mokytojų ir mokyklos administratorių elgesị. Viena vertus, tiesioginès kontrolès formos žlugdo ir motyvuoja mokytojus. Kita vertus, ịvairių kontrolès formų dèka mokytojai laikosi ir tęsia darbą, nepaisant augančio siekio maištauti prieš sistemą. Straipsnyje teigiama, kad COVID pandemija atskleidè anksčiau egzistuojančias problemas, todèl straipsnio išvados taip pat taikomos ne pandemijos kontekste.

Pawel Krzyworzeka, Associate Professor, Department of Management in the Network Society, Kozminski University

E-mail: pkrzyworzeka@kozminski.edu.pl 
Amanda Krzyworzeka, Assistant Professor, Institute of Ethnology and Cultural Anthropology, University of Warsaw

E-mail: a.krzyworzeka@uw.edu.pl

Pawel Krzyworzeka, docentas, Visuomenès vadybos katedra, Kozminski Universitetas

El. paštas: pkrzyworzeka@kozminski.edu.pl

Amanda Krzyworzeka, docentè, Etnografijos ir kultūros antropologijos institutas, Varšuvos Universitetas

El. paštas: a.krzyworzeka@uw.edu.pl

This article is an Open Access article distributed under the terms and conditions of the Creative Commons Attribution 4.0 (CC BY 4.0) License (http://creativecommons.org/licenses/by/4.0/ ). 